\title{
Letter from Pyrrandrus and other/s to Heracleides
}

\author{
CG $10298 \mathrm{a}+\mathrm{b}$ \\ $22 \times 14.4 \mathrm{~cm}$ \\ June $4^{\text {th }}, 243$ BCE
}

Gurob (Fayoum)

The document CG 10298 consists of two pieces: A, which has been edited by an Egyptian colleague (Belal Abu El-Ela) in his Master's thesis and later published in the Bulletin of the Center of Papyrological Studies and Inscriptions, Ain Shams University (BACPSI) 23 (2006), 77-81, ${ }^{(1)}$ and $\mathrm{B}$, which is being edited here.

This dark brown papyrus measures ca. $22 \mathrm{~cm}$ in width by $14.4 \mathrm{~cm}$ in height. It is of good quality. Although the papyrus has suffered significant damage, lacunae, loss and discoloration, especially at the middle and on the left, the preserved part is in relatively good condition. The surface is rugged. Some parts still need to be unfolded and cleaned. The fibers are frayed in the middle, wrinkled at the bottom right and misaligned at the bottom left, which does not significantly affect the text. It seems that the papyrus was folded vertically at right side (ca. $5 \mathrm{~cm}$ from the right edge). The left side of the papyrus is broken off, while the top, right and bottom margins are preserved. The ink is partially rubbed from some parts of line 8 , so that the writing is barely legible especially in the middle. There is a blot of ink almost in the middle of line 8 , probably caused by the scribe. The papyrus has been glued to the verso by modern chemise paper for reinforcement, as with many papyri in the Catalogue of Grenfell and Hunt. ${ }^{(2)}$

The papyrus has preserved 9 incomplete lines, which run against the fibers (transversa charta). The text has been written in black ink with a fine nib. The letters are large semi-uncials with no ligatures. The hand is slow, clear and moderately skilled with no calligraphic features. It is characterized by the following features: The $m u$ is produced by two curved vertical strokes with a more-or-less shallow curve which joins them. There are two kinds of alphas, where sometimes The scribe has written the alpha in two different shapes. The tau is a T-Shape, while upsilon is a Y-shape. The sigma is lunate, while the epsilon has a tongue attached to the middle. Iota is a simple short vertical stroke. The rho has a small head with a vertical stroke sometimes invading the interlinear space. The interlinear spaces are almost even. There is no punctuation or diacritical marks.

Besides the palaeographical indicators which place this document in the $3^{\text {rd }}$ century BCE, line 9 refers to the fourth year of Ptolemy most likely Ptolemy III Euergetes, who ruled from 246 to $-222 \mathrm{BCE}$. Another hint can be found in line $1{ }^{(3)}$ Accordingly, the date is most likely June $4^{\text {th }}, 243$ BCE.

As mentioned in the Catalogue General of Grenfell and Hunt "this document is probably from Gurob, Fayoum," modern Kom Madinet El-Gurab. I am actually inclined to believe that this is the place from which the papyrus came, since the only attestation

(1) There are some minor differences in this edition from Belal's readings (especially the restoration of the missing part), where the two pieces have been joined together and the general sense made relatively clearer.

(2) A large number of papyri in the catalogue of Grenfell and Hunt has been restored in this way and all of them are currently kept together and known as the "Chemise" papyri.

(3) See note on line 1 


\section{Letter from Pyrrandrus and other/s to Heracleides}

of the name Pyrrandrus is in P.Petr. 29(a), reprinted in P.Petr 3.117(b), "A Taxing Account on Vineyards," which dates to May 13, 245 BCE, and is from the Arsinoite. There are two persons who bear this name in the document: Pyrrandrus son of Demosthenes and Pyrrandrus son of Pyrrandrus.

The document is a letter from Pyrrandrus and others to Heracleides about the produce of a vineyard.

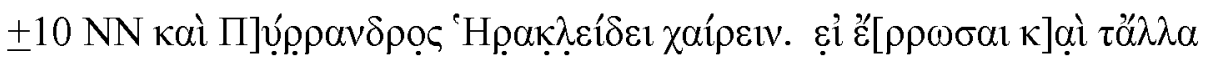
бọl

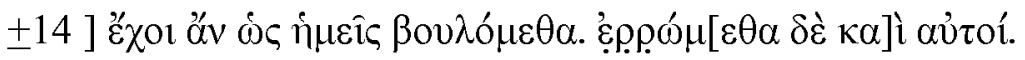

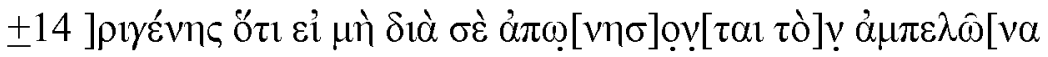

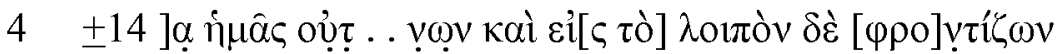

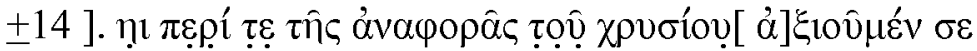

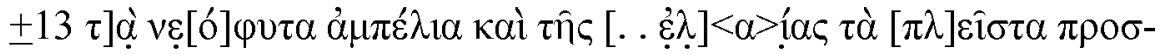

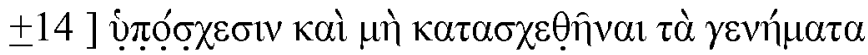

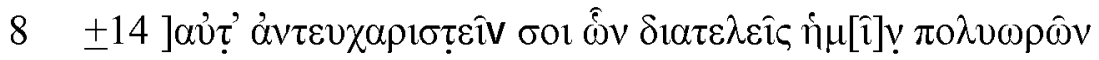

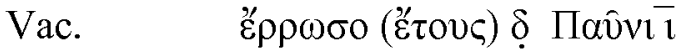

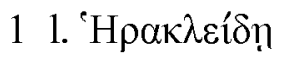

$\mathrm{NN}$ and Pyrrandrus to Herakleides greetings. If your health is good and your other concerns [are agreeable,] it would be as we wish. We too are well . . Perigenes/ Chairegenes, that if they will not buy the vineyard through you ... us . . . and you consider for the rest ... . we entreat you regarding the payment of the gold ... for the young plants of vine and of the olive, the greatest (largest) . . promise to pay and not withhold the produce ... the same (produce, ..... we are) thankful to you in return, that you continue giving extra care to us. Farewell. Year 4, Pauni 10th

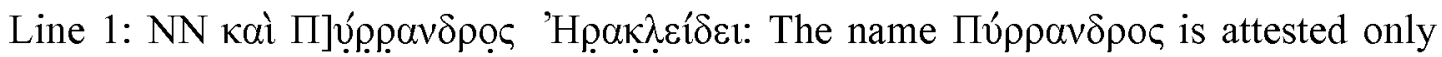
twice, in P.Petr. 2 29(a) (from 245 - 244), once as a son of Demosthenes and again as a son of Pyrrandrus. Since this document has been dated around the same time as P.Petr. 229 (i.e. $243 \mathrm{BCE}$ ) and both of them are from the Arsinoite, the person mentioned in this document could be either Pyrrandrus son of Demosthenes or Pyrrandrus son of Pyrrandrus.

From the syntax of the text (cf. $\alpha \xi_{10} \hat{\mu} \mu \varepsilon v$ in line 5, also the construction in line 2

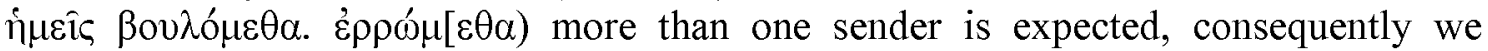
expect at least one other name before Пú $\rho \rho \alpha \delta \rho o s$.

Line 2: There are few possibilities for the restoration of the beginning of this line

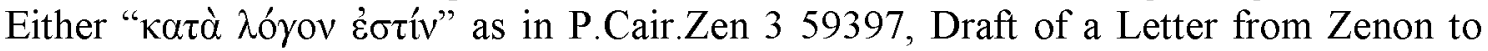
Themistocles (Arsinoite, 275 BCE - 226 BCE), SB 1 4304, Private Letter (Unknown, $300 \mathrm{BCE}-201 \mathrm{BCE}$ ).

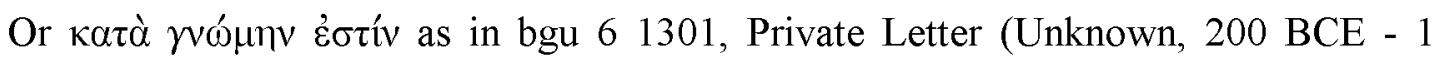
BCE), P.Cair.Zen 1 59056, Letter from Apollodotos to Zenon (Karien, 257 BCE), P.Petr. 2 2, Correspondence of Diophanes. Letter from Moschion (Arsinoite, 224 BCE - 


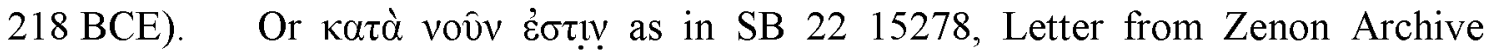
(Philadelphia, 246 BCE - 245 BCE).

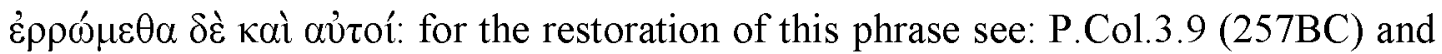
P.Mich.1.10 (257 BCE).

Depending on which restoration in the beginning of line 2 is correct, the number of missing letters could be from 13 to 15 letters. Thus an average of 14 letters, about one quarter of the papyrus, has been lost on the left hand side.

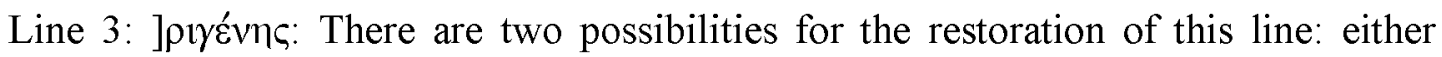
Пврı'́́vnc O.Bodl 1285 (Thebes?, 300 BCE - 101 BCE), P.Grad 7, Receipt of Royal Farmer for Seed (Unknown, 221 BCE - 203 BCE); or Xaıрı'́vnc P.Lond 7 1994, Philadelphia (Arsinoite), 251 BCE, P.Lond 71995 (Philadelphia, 251 BCE). Another possible restoration for name is ' $\Omega$ pryévms, yet this name is attested only once in Ptolemaic era "during the $2^{\text {nd }}$ BCE" in P.Amh 2 62, List of Soldiers, Soknopaiu Nesos (Arsinoites), while this document dates back to the middle of the third century CE.

$\dot{\alpha} \pi \omega[v \eta \sigma] \underline{v}[\tau \alpha 1:$ Although the letters are not certain, the reading still provides a reasonable meaning for the context.

Line 4: There are traces of an alpha at the beginning of the line.

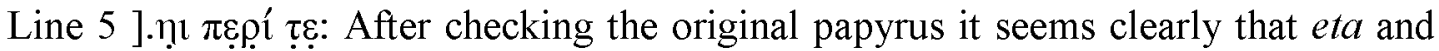
iota are legible and after the preposition $\pi € ̣ \rho$ í there are traces of vertical stroke of the tau then epsilon.

Line 6: $\tau \hat{\eta} \varsigma .$. छ̇ $\lambda \dot{i} \alpha \varsigma$ Before $\pi \lambda \varepsilon \hat{\imath} \sigma \tau \alpha$ at the end of line $6 \tau \hat{\eta} \varsigma$ is legible before the lacuna then the lacuna fits about two letters, then $\varepsilon^{\prime} \lambda \dot{i} \alpha \varsigma$ and $\tau \dot{\alpha} \pi \lambda \varepsilon \hat{i} \sigma \tau \alpha$. Although the missing part at the middle of this line fits for about three letters (cf. line 7), including the sigma of the article $\tau \hat{\eta} \varsigma$, the construction does not allow additional words; the writer could have left a blank area between the article and $\dot{\varepsilon} \lambda i^{\prime} \alpha \varsigma$.

The usual form is $\dot{\varepsilon} \lambda \alpha i \alpha \varsigma$, but sometimes appears as $\dot{\varepsilon} \lambda \alpha \dot{\alpha} \alpha$ or $\dot{\varepsilon} \lambda \hat{\alpha}$. For the exchange between $\alpha_{l}>l$ see, E Mayser, Grammattik der Griechischen Papyri aus der Ptolemäerzeit. Laut-Und Wortlehre, pp 103/106.

Line 7 ịo $\sigma \chi \varepsilon \sigma 1 v:$ The papyrus is mutilated at the beginning of this line, where ị $\pi 0 . \sigma-$ can barely be read.

Line 8: $\dot{\alpha} v \tau \varepsilon v \chi \alpha \rho ı \tau \varepsilon i v$ this compound infinitive form has never been attested before in the documents. The verb gives the impression of a big favor or at least the expectation of continued support from the part of the addressee.

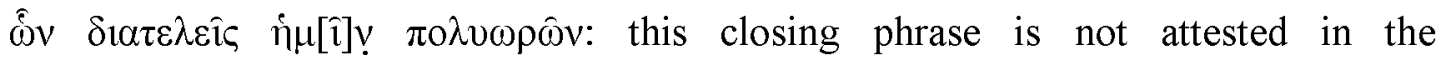
correspondences before.

Magdy Aly 


\section{Letter from Pyrrandrus and other/s to Heracleides}

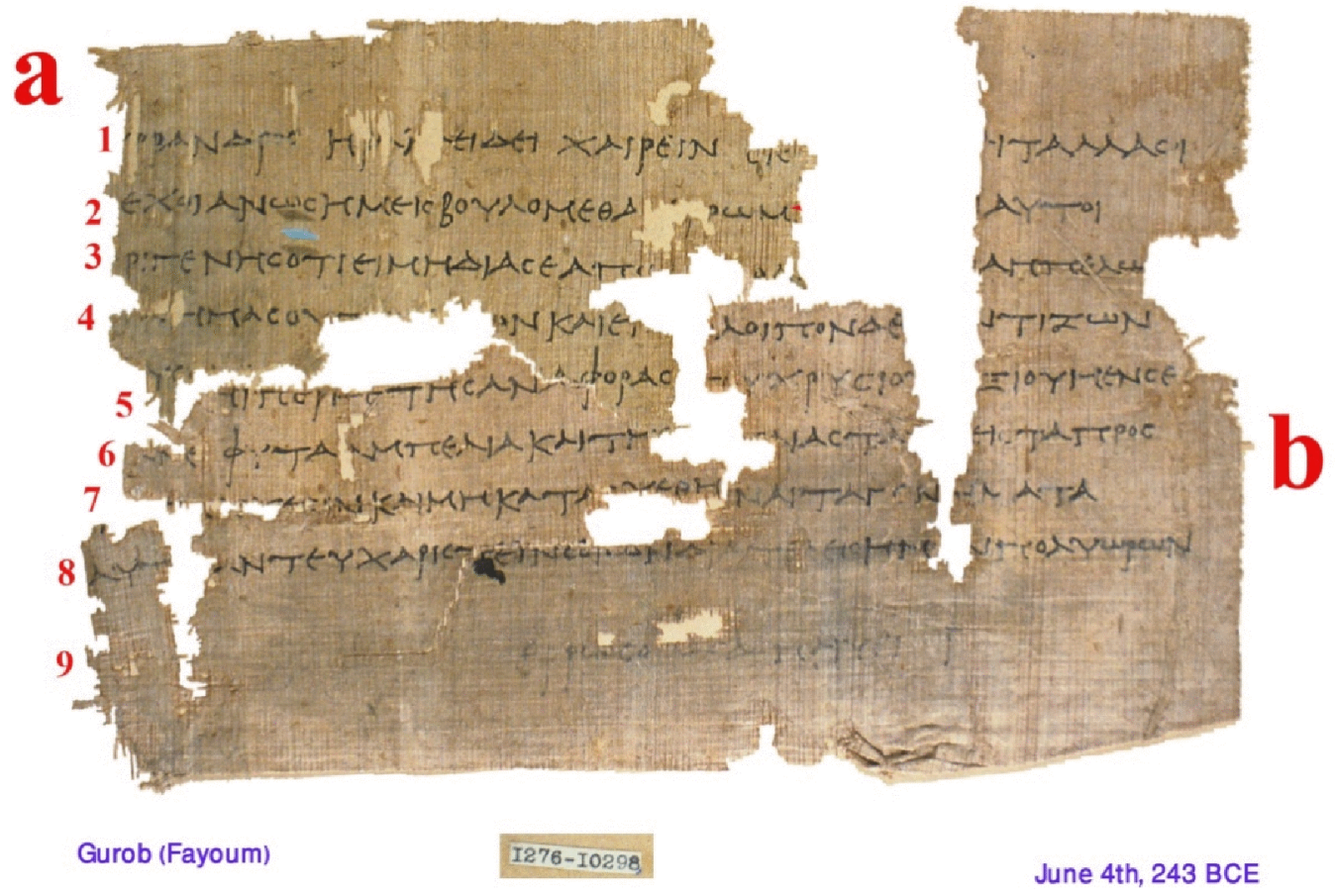

